\title{
PENAKSIRAN KONTAMINASI LOGAM BERAT DAN KUALITAS SEDIMEN SUNGAI CIMADUR, BANTEN
}

\section{ASSESSMENT OF HEAVY METAL CONTAMINATION AND SEDIMENT QUALITY IN THE CIMADUR RIVER, BANTEN}

\author{
Th. Rina Mulyaningsih, Siti Suprapti \\ Pusat Sains dan Teknologi Bahan Maju - BATAN \\ Kawasan Puspiptek Gedung No. 42, Serpong 15314 \\ e-mail: thrinam@batan.go.id
}

Diterima 4 September 2014, diterima dalam bentuk perbaikan 26 November 2014, disetujui 13 Januari 2015

\begin{abstract}
ABSTRAK
PENAKSIRAN KONTAMINASI LOGAM BERAT DAN KUALITAS SEDIMEN SUNGAI CIMADUR, BANTEN. Asesmen kualitas sedimen sungai dapat dilakukan melalui perhitungan indek polusi. Adanya kegiatan penambangan emas di Cikotok, ditengarai berdampak terhadap penurunan kualitas sungai Cimadur. Telah dilakukan perhitungan indeks polusi oleh logam berat $\mathrm{Hg}$, As, Cr, Co dan $\mathrm{Zn}$ terkandung dalam sedimen Sungai Cimadur Cikotok Banten. Sampling sedimen dilakukan di 9 lokasi sampling sepanjang sungai Cimadur. Kuantifikasi logam berat dalam sampel dilakukan dengan menggunakan teknik analisis aktivasi neutron. Hasil asesmen berdasarkan nilai faktor pengkayaan menunjukkan bahwa telah terjadi peningkatan konsentrasi logam berat $\mathrm{Hg}$, As, Cr, Co dan Zn karena faktor antropogenik. Berdasarkan nilai indeks geoakumulasi diketahui bahwa lokasi sampling telah tercemar, terutama oleh $\mathrm{Hg}$ dan As. Logam berat terkandung dalam sedimen memberikan resiko ekologis terhadap lingkungan dengan urutan $\mathrm{Cr}<\mathrm{Zn}<\mathrm{As}<\mathrm{Hg}$. Berdasarkan nilai indeks beban polusi (PLI), semua lokasi sampling tercemar oleh logam berat $\mathrm{Hg}$, As, Cr, Co dan Zn. Logam berat ini dapat bersumber dari bebatuan alam dan karena kegiatan penambangan emas. Evaluasi berdasarkan nilai indeks resiko ekologis potensial, menunjukkan bahwa pencemaran logam berat ini akan memberikan dampak resiko ekologis terhadap lingkungan sekitarnya dari tingkat rendah hingga tinggi, sehingga perlu pemantauan dan pengelolaan lingkungan yang tepat untuk menurunkan beban pencemaran yang ada di lokasi tersebut.
\end{abstract}

Kata kunci: sedimen, logam berat, indeks polusi, resiko ekologis

\begin{abstract}
ASSESSMENT OF HEAVY METAL CONTAMINATION AND SEDIMENT QUALITY IN THE CIMADUR RIVER, BANTEN. River sediment quality assessment can be done by the calculation of pollution index. The existence of gold mining activities in Cikotok suspected to have an impact on Cimadur river quality degradation. Calculations pollution index by heavy metal $\mathrm{Hg}, \mathrm{As}, \mathrm{Cr}$, Co and $\mathrm{Zn}$ contained in river sediment Cimadur Cikotok Banten have been performed. Sediment sampling has conducted at 9 locations along the Cimadur River. Quantification of heavy metals in the samples was done by using the neutron activation analysis technique. The result of assessment based on enrichment factor showed that there has been an increase in concentration of heavy metals $\mathrm{Hg}, \mathrm{As}, \mathrm{Cr}, \mathrm{Co}$ and $\mathrm{Zn}$ due to anthropogenic factors. Based on the value of index geoaccumulation it was known that the sampling location has been polluted, predominantly by $\mathrm{Hg}$ and $\mathrm{As}$. Heavy metals contained in the sediments provide ecological risk to the environment with following order: $\mathrm{Cr}<$ $\mathrm{Zn}<\mathrm{As}<\mathrm{Hg}$. Based on the value of pollution load index (PLI), all locations were polluted by heavy metals $\mathrm{Hg}$, As, $\mathrm{Cr}$, Co and $\mathrm{Zn}$. The sources of heavy metals could be from natural rocks or gold mining activities. Evaluation based on potential ecological risk index, showed that heavy metal pollution will give impact of ecological risk to the surrounding environment from low level to high, so it is necessary to do environmental monitoring and management appropriate for reducing the pollution in that location.
\end{abstract}

Keywords: sediment, heavy metal, pollution index, ecological risk 


\section{PENDAHULUAN}

Sedimen dapat digunakan sebagai indikator yang sensitif untuk monitoring kontaminan dalam lingkungan $S_{\text {perairan }}(1,2)$. Keberadaan kontaminan logam berat di perairan dapat bersumber dari litogenik maupun anthropogenic (3). Akumulasi kontaminan logam toksik seperti $\mathrm{Cd}, \mathrm{Hg}, \mathrm{Pb}, \mathrm{Cu}, \mathrm{Ni}, \mathrm{Cr}$ dan $\mathrm{Zn}$ dalam sedimen dapat mengakibatkan masalah yang serius terhadap lingkungan. Kualitas perairan menjadi turun dan menyebabkan bioasimilasi dan bio-akumulasi logam terhadap organisme perairan yang dalam jangka panjang dapat memberikan implikasi terhadap kesehatan manusia melalui rantai pangan dan ekosistem (4), sehingga pencemaran lingkungan oleh logam berat banyak mendapat perhatian pada beberapa dekade belakangan baik di negara maju maupun berkembang $(2,4,5)$.

Sungai Cimadur terletak di wilayah Lebak. Berdasarkan beberapa artikel yang dimuat di media cetak, diketahui bahwa di sekitar Sungai Cimadur sering diketemukan kasus kematian ikan sungai, yang menandakan bahwa kualitas sungai ini sudah mengalami penurunan. Air sungai digunakan oleh masyarakat untuk menunjang aktivitas sehari-hari, sehingga penurunan kualitas sungai dalam jangka waktu tertentu dapat berdampak terhadap kesehatan masyarakat.

Logam berat dalam sedimen perairan bisa berasal dari berbagai kegiatan seperti pertanian, industri, rumah tangga dan pertambangan. Demikian juga dengan logam berat yang terkandung dalam sedimen yang diambil dari Sungai Cimadur dapat berasal dari kegiatan yang ada di sekitar perairan tersebut. Penambangan emas di Cikotok telah beroperasi cukup lama, walaupun pengoperasian oleh PT Aneka Tambang telah dihentikan tahun 2011, tetapi hingga saat ini penambangan tradisional masih berlangsung dilakukan oleh rakyat yang disebut Gurandil. Penambangan ini dalam pelaksanaannya menggunakan proses kimia seperti sianidasi dan amalgamasi untuk memisahkan emas dari bijih emas (6). Adanya kegiatan penambangan emas ini kemungkinan dapat meningkatkan konsentrasi kontaminan logam berat di perairan, yang pada dasarnya sudah terkandung dalam bahan tambang ditambah limbah proses kimia yang digunakan pada penambangan. Oleh karena itu penurunan kualitas Sungai Cimadur kemungkinan sebagai dampak kegiatan penambangan yang ada di daerah tersebut. Untuk mengevaluasi kondisi sungai maka diperlukan adanya monitoring, kuantifikasi dan analisis kualitas sungai yang dapat dilakukan melalui perhitungan beberapa indek polusi oleh logam berat yang terkandung dalam sedimen sungai $(5,7)$. Parameter indeks polusi yang akan dihitung meliputi faktor pengkayaan $(E F)$, faktor kontaminasi $\left(C_{f}\right)$, indeks geoakumulasi $\left(I_{g e o}\right)$, faktor resiko ekologis $\left(E_{r}\right)$, indeks beban polusi $(P L I)$, derajat kontaminasi $\left(C_{d}\right)$ dan indeks resiko ekologis potensial $(R I)$. Untuk itu telah dilakukan analisis kualitas sungai Cimadur berdasarkan evaluasi beberapa indeks polusi. Diharapkan dari kegiatan ini dapat diketahui kualitas sungai Cimadur, sehingga langkah strategis untuk peningkatan kualitas perairan dapat dilakukan dengan tepat.

\section{METODOLOGI}

\section{Pengambilan Sampel}

Sampel sedimen diambil secara random di beberapa titik sampling di sepanjang Sungai Cimadur yang terletak di dekat lokasi penambangan emas Cikotok (Gambar 1). Jarak antar lokasi sampling adalah 5 - $10 \mathrm{~km}$. Koordinat lokasi sampling ditampilkan dalam Tabel 1. Disetiap lokasi sampling diambil tiga titik sampling dengan jarak masing-masing sekitar $10 \mathrm{~m}$ antara satu titik dengan lainnya. Sampel sedimen diambil pada kedalaman 10 $20 \mathrm{~cm}$ dari permukaan dengan menggunakan alat pengambil sampel yang terbuat dari pipa PVC. Sampel sedimen dimasukkan dalam kantong plastik yang telah diberi tanda (kode), untuk selanjutnya dibawa ke laboratorium untuk dilakukan proses preparasi.

\section{Preparasi Sampel}

Sampel sedimen dikeringkan di bawah sinar matahari selama 3 - 4 hari, kemudian dilakukan penggerusan dengan menggunakan mortar dan pastel dan selanjutnya dilakukan pengayakan untuk mendapatkan butiran yang seragam dan homogen. Sampel sedimen selanjutnya ditimbang dalam vial low density polyethylene, LDPE 20 - 50 $\mathrm{mg}$ dengan menggunakan neraca mikro dari Sartorius. 


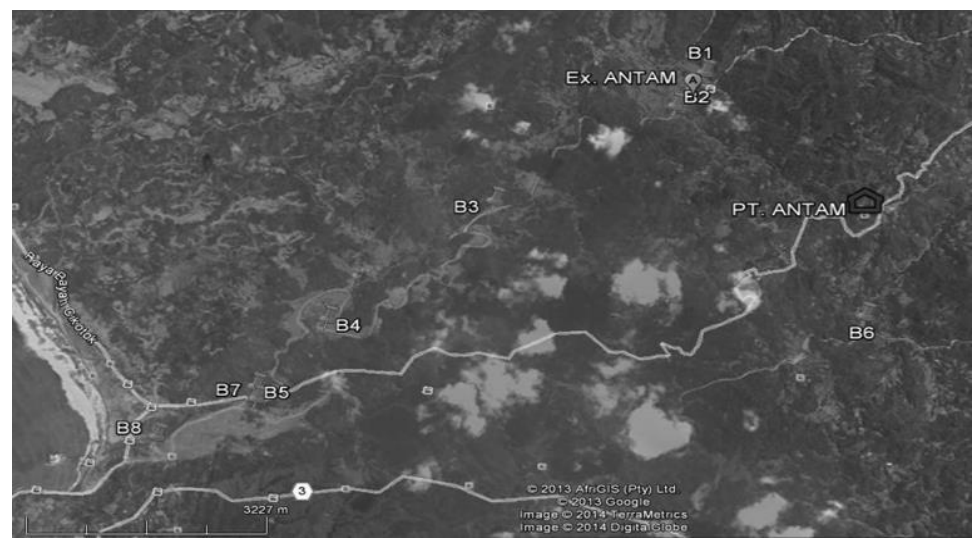

Gambar 1. Lokasi pengambilan sampel sedimen (8).

Tabel 1. Koordinat pengambilan sampel sedimen di Sungai Cimadur.

\begin{tabular}{ccc}
\hline \multirow{2}{*}{ Lokasi } & \multicolumn{2}{c}{ Koordinat } \\
& Garis Bujur & Garis Lintang \\
\hline B01 & $608566,7^{\prime \prime}$ & $106027^{\prime} 67,0^{\prime \prime}$ \\
B02 & $6085^{\prime} 84,3^{\prime \prime}$ & $106027^{\prime} 63,6^{\prime \prime}$ \\
B03 & $6089^{\prime} 07,4^{\prime \prime}$ & $106026^{\prime} 56,9^{\prime \prime}$ \\
B04 & $6091^{\prime} 24,5^{\prime \prime}$ & $106025^{\prime} 85,1^{\prime \prime}$ \\
\hline
\end{tabular}

\begin{tabular}{ccc}
\hline \multirow{2}{*}{ Lokasi } & \multicolumn{2}{c}{ Koordinat } \\
& Garis Bujur & Garis Lintang \\
\hline B05 & $6092^{\prime} 71,3^{\prime \prime}$ & $106025^{\prime} 75,2^{\prime \prime}$ \\
B06 & $6087^{\prime} 53,2^{\prime \prime}$ & $106031^{\prime} 18,1^{\prime \prime}$ \\
B07 & $6092^{\prime} 71,3^{\prime \prime}$ & $1060266^{\prime} 01,2^{\prime \prime}$ \\
B08 & $6093^{\prime} 98,7^{\prime \prime}$ & $106024^{\prime} 90,3^{\prime \prime}$ \\
\hline
\end{tabular}

\section{Preparasi Target dan Pencacahan}

Sampel yang telah ditimbang di dalam vial dibungkus dengan aluminium foil dan disusun menjadi satu target yang siap untuk diaktivasi. Target ini terdiri atas sampel sedimen, bahan acuan standar (SRM) 2704 Buffalo river sediment dari NIST (National Institute of Science and Technology) dengan berat disesuaikan dengan berat sampel, dan pemantau fluks Al-0,1\% Au dari IRMM (Institute for Reference Material and Measurement) dengan berat 2 - 3 mg. Target dimasukkan ke dalam kapsul iradiasi dan diaktivasi selama 10 menit untuk analisis unsur dengan waktu paro sedang dan 3 jam untuk analisis unsur dengan waktu paro panjang (Tabel 2). Aktivasi dilakukan di Sistem Rabbit Reaktor Serbaguna G.A. Siwabessy pada fluks neutron $\approx 10^{13} \mathrm{n}$. $\mathrm{cm}^{-2}$. $\mathrm{dt}^{-2}$. Pencacahan menggunakan detektor HPGe dari Canberra dengan efisiensi detektor $25 \%$.

Tabel 2. Kondisi aktivasi dan pencacahan sampel sedimen.

\begin{tabular}{|c|c|c|c|c|}
\hline $\begin{array}{l}\text { Waktu iradisi } \\
\text { (berat) }\end{array}$ & Posisi iradiasi & Waktu Peluruhan & $\begin{array}{c}\text { Waktu } \\
\text { Pencacahan }\end{array}$ & Isotop \\
\hline $\begin{array}{l}10 \text { menit } \\
(\sim 30 \mathrm{mg})\end{array}$ & $\begin{array}{c}\text { Sistem Rabbit } \\
\left(\sim 3 \times 10^{13} \mathrm{n} \cdot \mathrm{cm}^{2} \cdot \mathrm{s}^{-1}\right)\end{array}$ & 2 - 4 hari & 20 menit & ${ }^{76} \mathrm{As}$ \\
\hline $\begin{array}{c}2 \mathrm{jam} \\
(\sim 50 \mathrm{mg})\end{array}$ & $\begin{array}{c}\text { Sistem Rabbit } \\
\left(\sim 3 \times 10^{13} \mathrm{n} \cdot \mathrm{cm}^{2} \cdot \mathrm{s}^{-1}\right)\end{array}$ & 10 - 20 hari & 120 menit & $\begin{array}{c}{ }^{51} \mathrm{Cr},{ }^{59} \mathrm{Fe}, \\
{ }^{60} \mathrm{Co},{ }^{65} \mathrm{Zn},{ }^{124} \mathrm{Sb} \\
{ }^{201} \mathrm{Hg}\end{array}$ \\
\hline
\end{tabular}

\section{Evaluasi Data}

Evaluasi kualitas sedimen berdasarkan data kandungan logam berat dalam sedimen menggunakan beberapa indikator, yang dapat dikelompokkan ke dalam indeks tunggal dan indeks terpadu (5). Indeks tunggal adalah indikator yang digunakan untuk menghitung kontaminasi dari logam tunggal (hanya satu logam berat) yang meliputi: faktor pengkayaan (enrichment factor), faktor kontaminasi (contamination factor), faktor resiko ekologis (ecological risk factor), dan indeks geoakumulasi (index of geo-accumulation). Untuk mengetahui kualitas sedimen berdasarkan perpaduan beberapa logam berat terkandung di dalamnya, digunakan indeks terpadu, yang meliputi: derajat kontaminasi (contamination degree), indeks resiko ekologikal potensial (potential ecological risk index) dan indeks beban polusi ( pollution load index). 


\section{Faktor Pengkayaan (EF)}

Faktor pengkayaan dapat digunakan untuk memperkirakan pengaruh antropogenik terhadap tanah, sedimen, limbah pertambangan, dan material lingkungan lainnya ${ }^{(9)}$. EF dihitung berdasarkan persamaan berikut:

$$
E F=\left(C_{i} / C_{i e}\right) S /\left(C_{i} / C_{i e}\right)_{R S}
$$

dimana $C_{i}$ adalah konsentrasi unsur i dalam sampel diamati, dan $C_{i e}$ adalah konsentrasi unsur stabil dalam sampel. Jadi $=\left(C_{i} / C_{i e}\right) s$ adalah perbandingan antara konsentrasi logam berat dengan unsur stabil dalam sampel diteliti, $\operatorname{dan}\left(C_{\mathrm{i}} / C_{\mathrm{ie}}\right)_{\mathrm{RS}}$ adalah perbandingan konsentrasi logam berat dengan unsur stabil dalam sampel standar ${ }^{(10)}$. Sebagai sampel standar biasanya digunakan kerak bumi (crust) atau sampel latar di lokasi tersebut. Sebagai unsur stabil dapat digunakan $\mathrm{Al}{ }^{(11,12)}$, Li, Sc, $\mathrm{Zr}{ }^{(13)}$ dan $\mathrm{Fe}{ }^{(10)}$. Data $C_{\text {i }}$ dalam sampel standar dapat menggunakan data kelimpahan dari Wedepohl (14). Fe dipilih sebagai unsur untuk normalisasi karena kadarnya yang tinggi di alam (7). Berikut kriteria evaluasi berdasarkan nilai $E F: E F<2$ tidak ada pengkayaan, $2 \leq E F<5$ pengkayaan sedang, $5 \leq$ $E F<20$ pengkayaan signifikan, $20 \leq E F<40$ pengkayaan sangat tinggi, $E F>40$ pengkayaan ekstrim tinggi (11).

\section{Indek Geoakumulasi $\left(I_{\text {geo }}\right)$}

Indeks geoakumulasi digunakan untuk menentukan kondisi kontaminasi oleh logam dalam sedimen ${ }^{(15,16)}$, dihitung menggunakan persamaan yang dikembangkan oleh Muller di tahun 1969 sebagai berikut:

$$
I_{\text {geo }}=\log _{2}\left[\frac{C \mathrm{i}}{1,5 \times C \mathrm{ri}}\right]
$$

dimana $C_{i}$ konsentrasi logam i dalam sampel sedimen dan $C_{r i}$ konsentrasi logam i dalam sedimen latar atau nilai acuan. Nilai latar dapat diukur atau diambil dari pustaka untuk data latar dari sedimen (3). Faktor 1,5 digunakan karena kemungkinan adanya variasi nilai dalam latar seperti adanya pengaruh antropogenik. Terdapat 7 tingkat nilai indeks geoakumulasi untuk menggambarkan kualitas sedimen (17). $I_{\text {geo }} \leq 0$ tidak tercemar, $0<I_{\text {geo }} \leq 1$ tidak tercemar sampai tercemar sedang, $1<I_{\text {geo }} \leq 2$, tercemar sedang, $2<I_{\text {geo }} \leq 3$ tercemar sedang hingga sangat tercemar, $3<I_{\text {geo }} \leq 4$ sangat tercemar, $4<I_{\text {geo }} \leq 5$ sangat tercemar hingga ekstrim tercemar dan $I_{\text {geo }} \geq 6$ ekstrim tercemar.

\section{Faktor Kontaminasi $\left(C_{\mathrm{F}}\right)$}

Faktor kontaminasi menggambarkan kondisi kontaminasi yang diakibatkan oleh bahan toksik pada sedimen di perairan ${ }^{(18)}$.

$$
C_{F}=\frac{\bar{C}_{0-i}}{C_{n}}
$$

di mana $\bar{C}_{0-i}$ adalah nilai rataan kadar logam i pada lokasi sampling dan $C_{n}$ adalah nilai acuan $n$ pada kondisi lokasi sebelum ada industri. Nilai acuan dapat digunakan dari nilai pra industri beberapa danau di Eropa dan Amerika, seperti pada tabel berikut.

Tabel 3. Nilai acuan Pra-Industri $(\mu \mathrm{g} / \mathrm{g})$ dan faktor respons toksik (18).

\begin{tabular}{lccccccc}
\hline Unsur & $\mathrm{Hg}$ & $\mathrm{Cd}$ & $\mathrm{As}$ & $\mathrm{Cu}$ & $\mathrm{Pb}$ & $\mathrm{Cr}$ & $\mathrm{Zn}$ \\
\hline Nilai acuan Pra-industri & 0,25 & 1,0 & 15 & 50 & 70 & 90 & 175 \\
Faktor respon toksik (Tr) & 40 & 30 & 10 & 5 & 5 & 2 & 1 \\
\hline
\end{tabular}

Kriteria berikut digunakan untuk menggambarkan kondisi kontaminasi : $C_{F}<1$ menunjukkan kontaminasi rendah, $1 \leq C_{F}<3$ kontaminasi sedang, $3 \leq C_{F} \leq 6$ kontaminasi tinggi dan $C_{F}>6$ kontaminasi sangat tinggi.

\section{Faktor resiko ekologis $\left(E_{\mathrm{r}}\right)$}

Faktor resiko ekologis menggambarkan secara kuantitatif potensi resiko ekologis yang diakibatkan oleh kontaminan atau polutan ${ }^{(18,19)}$.

$$
E_{\mathrm{r}}=T_{\mathrm{r}}-C_{\mathrm{F}}
$$

di mana $T_{\mathrm{r}}$ adalah faktor respon toksik yang diberikan oleh bahan dan $C_{\mathrm{F}}$ adalah faktor kontaminasi. Nilai $T_{\mathrm{r}}$ untuk berbagai logam berat seperti tertera pada Tabel 3 . Kriteria berikut digunakan untuk menggambarkan faktor resiko ekologi, $E_{\mathrm{r}}<40$ potensial resiko ekologi rendah, $40 \leq E_{\mathrm{r}}<80$ potensial resiko ekologi sedang, $80 \leq E_{\mathrm{r}}<160$ potensial 
resiko ekologi besar, $160 \leq E_{\mathrm{r}}<320$ potensial resiko ekologi tinggi dan $E_{\mathrm{r}} \geq 320$ potensial resiko ekologi sangat tinggi.

\section{Derajat kontaminasi $\left(\boldsymbol{C}_{\mathrm{d}}\right)$}

$C_{d}$ merupakan indeks gabungan, digunakan untuk menggambarkan tingkat kontaminasi dari unsur-unsur toksik dalam sedimen $(5,18)$.

$$
C_{d}=\sum_{i=j}^{m} C_{f}^{i}
$$

$C_{d}$ diperoleh dengan menjumlahkan faktor kontaminasi unsur logam berat tunggal terkandung dalam sedimen. Untuk mendiskripsikan derajat kontaminasi digunakan terminologi sebagai berikut: $C_{d}<m$ kontaminasi tingkat rendah, $m \leq C_{d}<2 m$ kontaminasi tingkat sedang, $2 m \leq C_{d}<4$ kontaminasi tingkat tinggi, $C_{d}>4 m$ kontaminasi sangat tinggi dimana $m$ adalah jumlah unsur toksik dalam sedimen yang diperhitungkan(20).

\section{Indek Resiko Ekologikal Potensial (RI)} sedimen $(5,18)$

$R /$ merupakan indeks gabungan, digunakan untuk memperkirakan resiko ekologikal logam berat dalam

$$
R I=\sum_{i=j}^{m} E r^{i}
$$

$R /$ merupakan jumlah dari Er faktor resiko ekologi dari logam berat i hingga $m$ yang terdapat dalam sedimen dan diperhitungkan dalam penentuan nilai $R /$. Kriteria nilai $R /$ berkaitan dengan resiko ekologis adalah $R /<150$ resiko ekologis rendah, $150 \leq R I<300$ resiko ekologis sedang, $300 \leq R I<600$ resiko ekologis tinggi dan $R I>600$ resiko ekologis sangat tinggi.

\section{Indek Beban polusi (PLI)}

$P L I$ merupakan indek gabungan, digunakan untuk memperkirakan tingkat polusi dari gabungan unsur logam berat dalam sedimen.

$$
P L I=\sqrt[n]{C_{f}^{1} C_{f}^{2} . . C_{f}^{n}}
$$

$C_{f}$ adalah faktor kontaminasi dari masing-masing unsur logam berat. $P L I<1$ berarti tidak ada polusi, $P L I>1$ polusi, $P L I=0$ nilai dasar (baseline level) (17,21).

\section{HASIL DAN PEMBAHASAN}

Hasil analisis kuantitatif sampel sedimen yang diambil dari Sungai Cimadur dengan metode AAN tertera dalam Tabel 4. Untuk meyakinkan bahwa data hasil kuantifikasi valid, telah dilakukan kontrol mutu internal metode, melalui pengujian bahan acuan standar yang memiliki matrik sejenis SRM 2704 Buffallo river sedimen. Hasil kontrol mutu menunjukkan bahwa hasil kuantifikasi logam $\mathrm{Fe}, \mathrm{Co}, \mathrm{As}, \mathrm{Sb}, \mathrm{Cr}$ dan $\mathrm{Zn}$ diperoleh dibandingkan nilai sertifikat $\approx 1$, jadi hasil uji di laboratorium hampir sama dengan nilai sertifikat ${ }^{(7)}$. Untuk mengetahui pengaruh antropogenik terhadap kualitas sedimen, dilakukan perhitungan nilai faktor pengkayaan (EF) untuk unsur logam berat dalam sedimen. Hasil evaluasi ditampilkan dalam Gambar 2.

Faktor pengkayaan $(E F)$ untuk $\mathrm{Hg}$ berkisar antara 3,14 - 30,22, berdasarkan kriteria evaluasi yang dilakukan oleh Sutherland ini berarti bahwa lokasi sampling telah mengalami pengkayaan oleh $\mathrm{Hg}$ dari tingkat sedang hingga sangat tinggi yang berasal dari efek anthropogenik. Nilai $E F$ untuk As berkisar antara 9,68 - 19,84, ini berarti bahwa semua lokasi penelitian sudah mengalami pengkayaan pada tingkat signifikan $(5 \leq E F<20)$. $E F$ untuk Sb antara 3,79 - 9,14 berarti sudah ada pengkayaan dari tingkat sedang hingga signifikan. Sedangkan $E F$ untuk $\mathrm{Zn}$ antara 1,41 - 7,81 yang berarti di beberapa lokasi belum ada pengkayaan tetapi di lokasi lainnya sudah ada pengkayaan pada tingkat signifikan (lokasi B01 dan B02). EF untuk $\mathrm{Cr}$ dan $\mathrm{Co}$ masih lebih kecil dari 2, ini menunjukkan bahwa lokasi penelitian belum mengalami pengkayaan dari logam berat $\mathrm{Cr}$ dan $\mathrm{Co}$.

Tabel 4. Konsentrasi logam berat (mg/kg) terkandung dalam sedimen Sungai Cimadur. 


\begin{tabular}{cccccccc}
\hline Lokasi & As & Co & $\mathrm{Cr}$ & $\mathrm{Fe}$ & $\mathrm{Hg}$ & $\mathrm{Sb}$ & $\mathrm{Zn}$ \\
\hline B01 & $54,46 \pm 0,83$ & $30,38 \pm 0,97$ & $122,86 \pm 2,44$ & $71491 \pm 1292$ & $4,55 \pm 0,56$ & $4,37 \pm 0,18$ & $1295,67 \pm 9,25$ \\
B02 & $60,81 \pm 0,91$ & $18,44 \pm 0,68$ & $60,06 \pm 1,64$ & $56104 \pm 831$ & $3,18 \pm 0,54$ & $2,85 \pm 0,14$ & $515,62 \pm 5,48$ \\
B03 & $39,27 \pm 1,63$ & $14,95 \pm 1,01$ & $37,23 \pm 3,21$ & $48919 \pm 1948$ & $5,35 \pm 0,56$ & $2,65 \pm 0,17$ & $368,80 \pm 24,45$ \\
B04 & $38,69 \pm 1,88$ & $16,60 \pm 0,37$ & $42,70 \pm 1,48$ & $52918 \pm 886$ & $2,41 \pm 0,45$ & $2,36 \pm 0,12$ & $297,40 \pm 8,78$ \\
B05 & $32,04 \pm 1,47$ & $17,07 \pm 0,57$ & $48,50 \pm 2,32$ & $51123 \pm 1512$ & $2,45 \pm 0,44$ & $1,95 \pm 0,14$ & $315,73 \pm 12,16$ \\
B06 & $65,91 \pm 1,11$ & $13,83 \pm 0,54$ & $32,50 \pm 1,40$ & $52190 \pm 947$ & $2,41 \pm 0,41$ & $2,45 \pm 0,18$ & $124,19 \pm 3,74$ \\
B07 & $85,66 \pm 2,80$ & $17,44 \pm 1,15$ & $113,34 \pm 7,62$ & $66700 \pm 1053$ & $1,05 \pm 0,08$ & $6,12 \pm 0,32$ & $161,90 \pm 13,19$ \\
B08 & $37,09 \pm 0,81$ & $15,76 \pm 0,20$ & $40,90 \pm 0,84$ & $43110 \pm 1331$ & $1,15 \pm 0,08$ & $2,43 \pm 0,08$ & $156,67 \pm 2,82$ \\
\hline
\end{tabular}

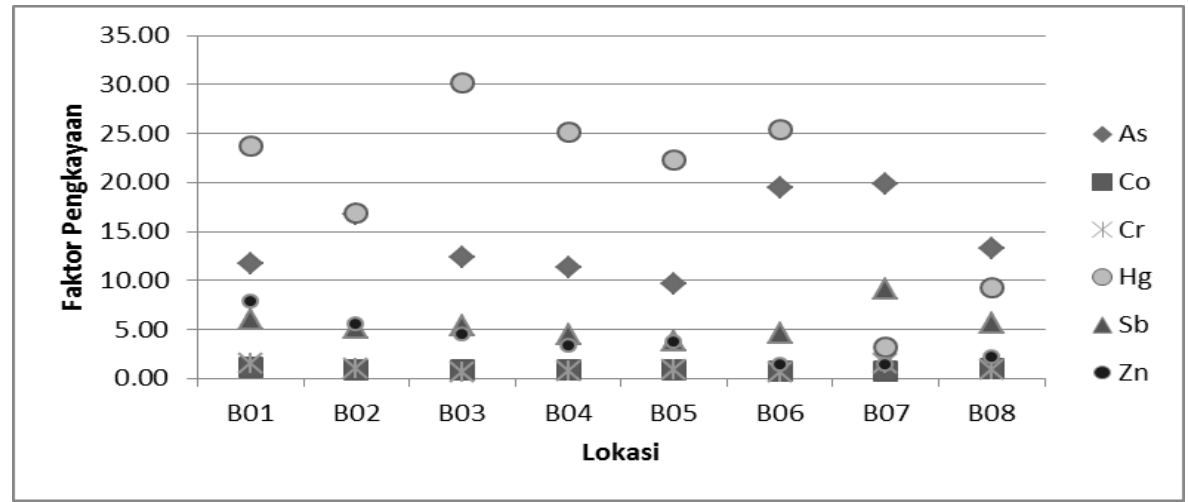

Gambar2. Faktor pengkayaan unsur logam berat dalam sedimen pada 8 lokasi sampling di Sungai Cimadur.

Hasil perhitungan indeks geoakumulasi untuk unsur $\mathrm{As}, \mathrm{Co}, \mathrm{Cr}$, $\mathrm{Hg}$ dan $\mathrm{Zn}$ ditampilkan dalam Gambar 3. Indeks geoakumulasi untuk $\mathrm{Hg} 0,31$ - 2,47, ini menunjukkan bahwa lokasi penelitian pada kondisi tercemar tingkat sedang hingga sangat tercemar oleh $\mathrm{Hg}$. Demikian juga untuk As berkisar antara 0,43-1,15, berarti lokasi penelitian pada kondisi tidak tercemar hingga tercemar tingkat sedang. Sedangkan indeks geoakumulasi untuk $\mathrm{Co}, \mathrm{Cr}$ dan $\mathrm{Zn} 0<I_{\text {geo }} \leq 1$, ini menunjukkan bahwa lokasi sampling pada kondisi tak tercemar hingga tercemar tingkat sedang.

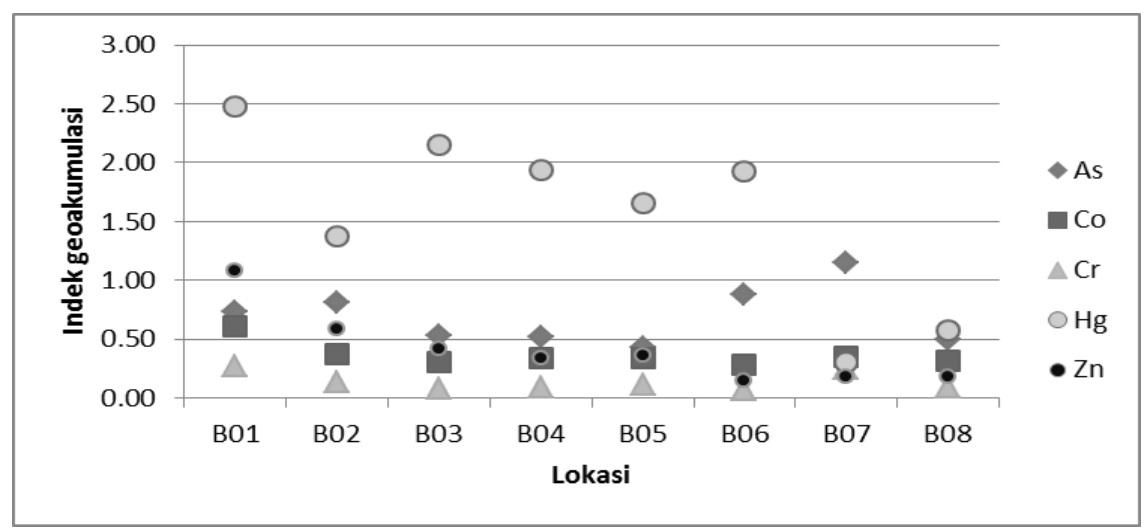

Gambar 3. Indeks geoakumulasi logam berat dalam sedimen pada 8 lokasi sampling di Sungai Cimadur. 


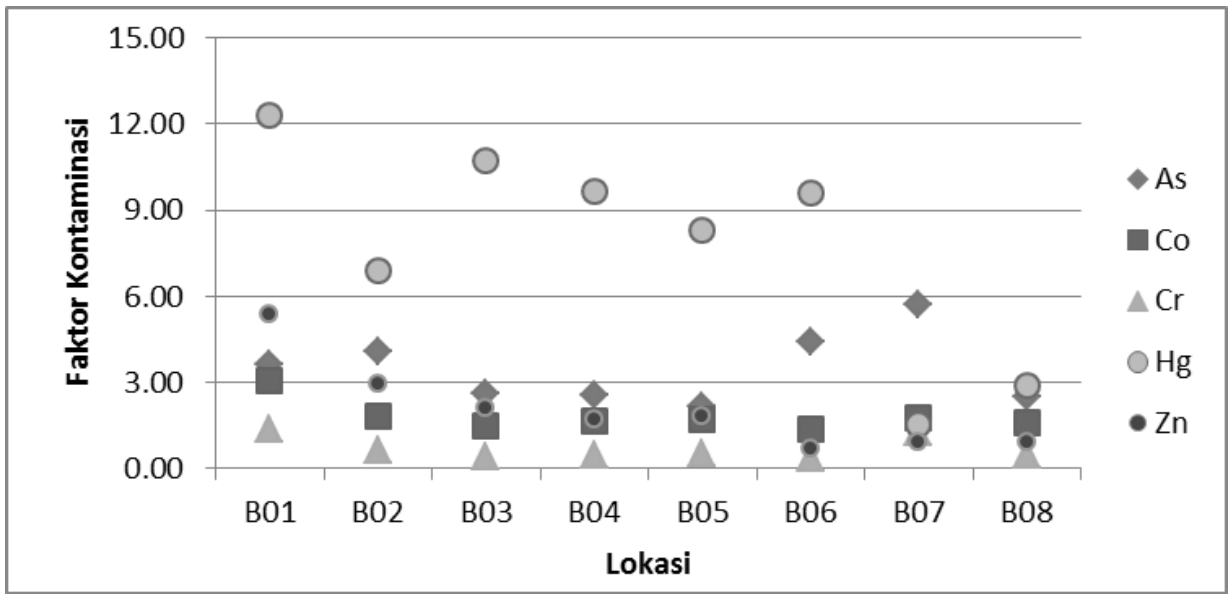

Gambar 4. Faktor kontaminasi logam berat dalam sedimen pada 8 lokasi sampling di Sungai Cimadur.

Faktor kontaminasi digunakan untuk menggambarkan tingkat kontaminasi yang disebabkan oleh unsur toksik dalam sedimen. Berdasarkan Gambar 4, dapat diketahui bahwa dengan mengacu kriteria berdasarkan nilai faktor kontaminasi, maka enam dari delapan lokasi sampling memiliki $C_{\mathrm{f}} \geq 6$ yaitu antara $6,88-12,32$ yang artinya bahwa pada lokasi tersebut telah terkontaminasi merkuri sangat tinggi, sedangkan lokasi B07 dan B08 terkontaminasi pada tingkat sedang nilai $C_{\mathrm{f}} 1,52$ dan 2,88. Arsen juga telah mengkontaminasi semua lokasi sampling dengan tingkat sedang dan paling tinggi ada di lokasi B07 dengan nilai $C_{f} 2,14-5,71$. Semua lokasi terkontaminasi tingkat rendah oleh $\mathrm{Cr}$ dan kontaminasi tingkat sedang oleh Co dan $\mathrm{Zn}$.

Faktor resiko ekologis digunakan untuk menggambarkan secara kuantitatif resiko ekologis potensial yang disebabkan oleh kontaminan logam toksik (Gambar 5). Asesmen berdasarkan faktor resiko ekologis dapat diurutkan $\mathrm{Cr}<\mathrm{Zn}<\mathrm{As}<\mathrm{Hg}$. Lima lokasi memiliki nilai $E_{\mathrm{r}} \geq 320$ yang artinya memiliki resiko ekologis sangat tinggi yang disebabkan oleh $\mathrm{Hg}$. Di lokasi B02, B06 dan B07 logam As memberikan nilai $40 \leq E_{\mathrm{r}}<80$ yang berarti bahwa As memberikan resiko ekologis pada tingkat sedang. Logam lainnya $\mathrm{Cr}$ dan $\mathrm{Zn}$ memberikan resiko ekologis potensial rendah dengan $E_{r}<40$ pada semua lokasi.

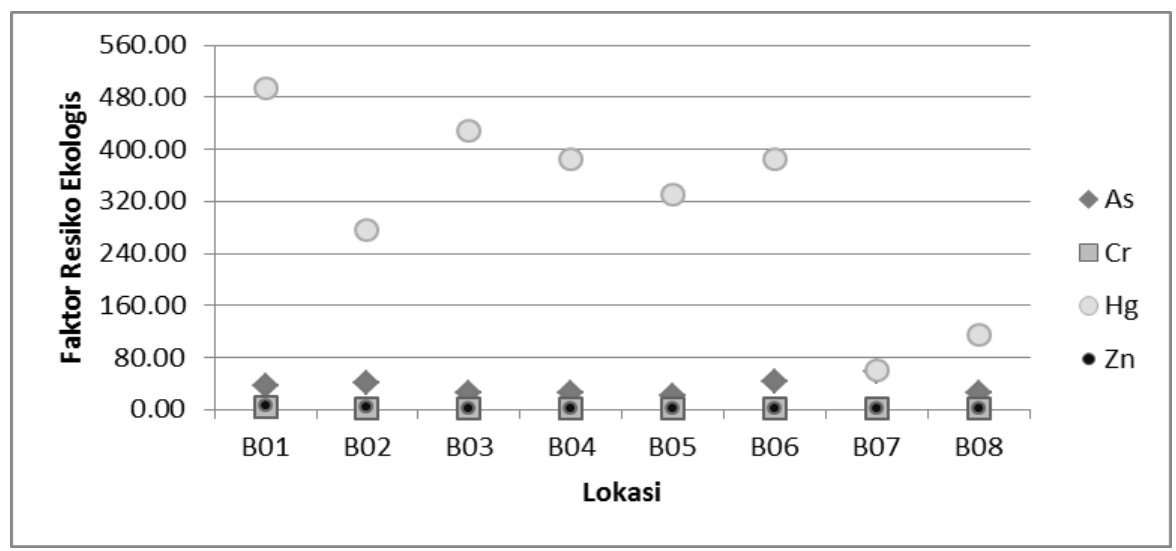

Gambar 5. Faktor resiko ekologis logam berat dalam sedimen pada 8 lokasi sampling di Sungai Cimadur.

Kondisi kualitas sungai Cimadur dapat dievaluasi berdasarkan nilai indek tunggal yang klasifikasinya tercantum dalam Tabel 5. 
Tabel 5. Klasifikasi kualitas sedimen berdasarkan parameter indeks tunggal (5).

\begin{tabular}{cccccc}
\hline Indeks & Tidak tercemar & Tercemar rendah & Tercemar sedang & Tercemar tinggi & Ekstrim tercemar \\
\hline$C_{\mathrm{f}}$ & $<2$ & $2-4$ & $4-16$ & $16-32$ & $>32$ \\
$E F$ & $<2$ & $2-4$ & $4-16$ & $16-32$ & $>32$ \\
$E_{\mathrm{r}}$ & $<2 T_{\mathrm{r}}$ & $2 T_{\mathrm{r}}-4 T_{\mathrm{r}}$ & $4 T_{\mathrm{r}}-16 T_{\mathrm{r}}$ & $16 T_{\mathrm{r}}-32 T_{\mathrm{r}}$ & $>32 T_{\mathrm{r}}$ \\
$I_{\text {geo }}$ & $<0,42$ & $0,42-1,42$ & $1,42-3,42$ & $3,42-4,42$ & $>4,42$ \\
\hline
\end{tabular}

Tabel 6. Klasifikasi kualitas sedimen Sungai Cimadur berdasarkan parameter indeks tunggal.

\begin{tabular}{|c|c|c|c|c|c|c|c|c|c|}
\hline \multirow{2}{*}{$\begin{array}{l}\text { Logam } \\
\text { Berat }\end{array}$} & \multirow[t]{2}{*}{ Indeks } & \multicolumn{8}{|l|}{ Lokasi } \\
\hline & & B01 & B02 & B03 & B04 & B05 & B06 & B07 & B08 \\
\hline As & $\begin{array}{l}C_{f} \\
E F \\
E_{r} \\
I_{g e o}\end{array}$ & $\begin{array}{l}\text { rendah } \\
\text { sedang } \\
\text { rendah } \\
\text { rendah }\end{array}$ & $\begin{array}{l}\text { sedang } \\
\text { tinggi } \\
\text { sedang } \\
\text { rendah }\end{array}$ & $\begin{array}{l}\text { rendah } \\
\text { sedang } \\
\text { rendah } \\
\text { rendah }\end{array}$ & $\begin{array}{l}\text { rendah } \\
\text { sedang } \\
\text { rendah } \\
\text { rendah }\end{array}$ & $\begin{array}{l}\text { rendah } \\
\text { sedang } \\
\text { rendah } \\
\text { rendah }\end{array}$ & $\begin{array}{l}\text { sedang } \\
\text { tinggi } \\
\text { sedang } \\
\text { rendah }\end{array}$ & $\begin{array}{l}\text { sedang } \\
\text { tinggi } \\
\text { sedang } \\
\text { rendah }\end{array}$ & $\begin{array}{l}\text { rendah } \\
\text { sedang } \\
\text { rendah } \\
\text { rendah }\end{array}$ \\
\hline $\mathrm{Hg}$ & $\begin{array}{l}C_{f} \\
E F \\
E_{r} \\
I_{\text {geo }}\end{array}$ & $\begin{array}{l}\text { sedang } \\
\text { ekstrim } \\
\text { sedang } \\
\text { sedang }\end{array}$ & $\begin{array}{l}\text { sedang } \\
\text { tinggi } \\
\text { sedang } \\
\text { sedang }\end{array}$ & $\begin{array}{l}\text { sedang } \\
\text { ekstrim } \\
\text { sedang } \\
\text { sedang }\end{array}$ & $\begin{array}{l}\text { sedang } \\
\text { tinggi } \\
\text { sedang } \\
\text { sedang }\end{array}$ & $\begin{array}{l}\text { sedang } \\
\text { tinggi } \\
\text { sedang } \\
\text { sedang }\end{array}$ & $\begin{array}{l}\text { sedang } \\
\text { tinggi } \\
\text { sedang } \\
\text { sedang }\end{array}$ & $\begin{array}{l}\text { rendah } \\
\text { sedang } \\
\text { rendah } \\
\text { rendah }\end{array}$ & $\begin{array}{l}\text { sedang } \\
\text { sedang } \\
\text { sedang } \\
\text { rendah }\end{array}$ \\
\hline $\mathrm{Cr}$ & $\begin{array}{l}C_{f} \\
E F \\
E_{r} \\
I_{g e o} \\
\end{array}$ & $\begin{array}{l}\text { tidak } \\
\text { tidak } \\
\text { tidak } \\
\text { tidak } \\
\end{array}$ & $\begin{array}{l}\text { tidak } \\
\text { tidak } \\
\text { tidak } \\
\text { tidak } \\
\end{array}$ & $\begin{array}{l}\text { tidak } \\
\text { tidak } \\
\text { tidak } \\
\text { tidak } \\
\end{array}$ & $\begin{array}{l}\text { tidak } \\
\text { tidak } \\
\text { tidak } \\
\text { tidak } \\
\end{array}$ & $\begin{array}{l}\text { tidak } \\
\text { tidak } \\
\text { tidak } \\
\text { tidak } \\
\end{array}$ & $\begin{array}{l}\text { tidak } \\
\text { tidak } \\
\text { tidak } \\
\text { tidak } \\
\end{array}$ & $\begin{array}{l}\text { tidak } \\
\text { tidak } \\
\text { tidak } \\
\text { tidak } \\
\end{array}$ & $\begin{array}{l}\text { tidak } \\
\text { tidak } \\
\text { tidak } \\
\text { tidak } \\
\end{array}$ \\
\hline $\mathrm{Zn}$ & $\begin{array}{l}C_{f} \\
E F \\
E_{\mathrm{r}} \\
I_{\text {geo }}\end{array}$ & $\begin{array}{l}\text { sedang } \\
\text { sedang } \\
\text { rendah } \\
\text { rendah }\end{array}$ & $\begin{array}{l}\text { sedang } \\
\text { sedang } \\
\text { rendah } \\
\text { rendah }\end{array}$ & $\begin{array}{l}\text { sedang } \\
\text { sedang } \\
\text { rendah } \\
\text { rendah }\end{array}$ & $\begin{array}{l}\text { tidak } \\
\text { rendah } \\
\text { tidak } \\
\text { tidak }\end{array}$ & $\begin{array}{l}\text { tidak } \\
\text { rendah } \\
\text { tidak } \\
\text { tidak }\end{array}$ & $\begin{array}{l}\text { tidak } \\
\text { tidak } \\
\text { tidak } \\
\text { tidak }\end{array}$ & $\begin{array}{l}\text { tidak } \\
\text { tidak } \\
\text { tidak } \\
\text { tidak }\end{array}$ & $\begin{array}{l}\text { tidak } \\
\text { rendah } \\
\text { tidak } \\
\text { tidak } \\
\end{array}$ \\
\hline
\end{tabular}

Evaluasi berdasarkan indeks tunggal yang meliputi nilai faktor kontaminasi $\left(C_{f}\right)$, faktor pengkayaan $(E F)$, indeks resiko ekologis $\left(E_{r}\right)$ dan indeks geoakumulasi untuk logam berat $\mathrm{As}, \mathrm{Hg}, \mathrm{Cr}$ dan $\mathrm{Zn}$ tercantum dalam Tabel 6. Berdasarkan Tabel 6 dapat diketahui bahwa kualitas sedimen di lokasi sampling di Sungai Cimadur adalah sedimen di semua lokasi sampling telah tercemar oleh arsenik dari level rendah hingga sedang, dan pada lokasi B02, B06, B07 berdasarkan nilai $E_{F} n y a$ maka pada lokasi ini sudah ada pengkayaan tingkat tinggi oleh arsenik.

Sedimen di semua lokasi telah tercemar oleh merkuri dari level rendah hingga sedang. Evaluasi berdasarkan nilai $E F$ menunjukkan, sudah ada pengkayaan oleh merkuri hingga level ekstrim untuk lokasi B01 dan B03, dan level tinggi pada lokasi B02, B04, B05 dan B06. Chromium tidak mencemari sedimen di semua lokasi penelitian, demikian juga dengan Zn, hanya mencemari sedimen di lokasi B01, B02 dan B03 pada level rendah hingga sedang.

Efek gabungan beberapa logam berat terkandung di dalam sedimen, dievaluasi berdasarkan perhitungan indeks gabungan yang meliputi, derajat kontaminasi $\left(C_{d}\right)$, indeks resiko ekologis potensial $(R I)$ dan Indeks beban polusi (PLI), hasil perhitungan ditampilkan dalam Gambar 6, 7 dan 8.

Berdasarkan nilai derajat kontaminasi gabungan 5 logam berat menunjukkan bahwa lokasi B01 sudah terkontaminasi sangat tinggi, lokasi B02 - B07 terkontaminasi level tinggi dan lokasi B08 terkontaminasi sedang.

Berdasarkan nilai indeks resiko ekologis potensial gabungan 4 logam berat, lokasi sampling B01 - B06 memiliki nilai $300 \leq R I<600$ berarti memiliki resiko ekologis tinggi dan 2 lokasi B07 dan B08 dengan $R I<150$ resiko ekologis rendah. Berdasarkan nilai indek beban polusi gabungan 5 logam berat, menunjukkan bahwa ke delapan lokasi sampling telah terkontaminasi $(P L I>1)$.

Keberadaan logam berat $\mathrm{As}, \mathrm{Hg}, \mathrm{Cr}$, Co dan $\mathrm{Zn}$ dalam sedimen sungai Cimadur kemungkinan besar bersumber dari adanya penambangan emas di daerah tersebut. Logam-logam tersebut sebenarnya secara alamiah berasal dari bebatuan di dalam perut bumi, misalnya arsenik dengan konsentrasi rata-rata 1,5 - 2 ppm. 


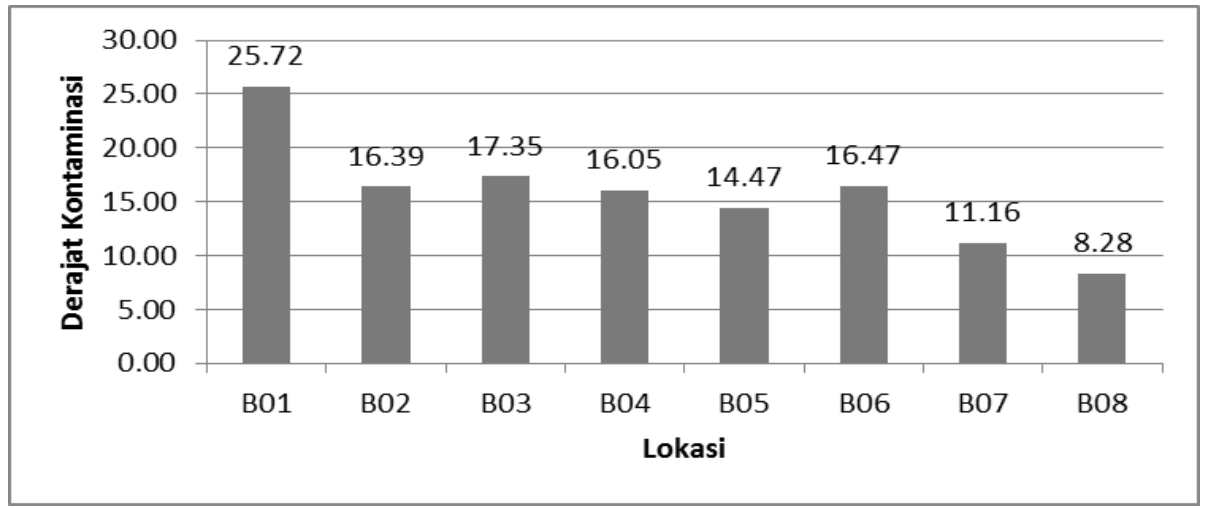

Gambar 6. Derajat kontaminasi gabungan logam berat $\mathrm{As}, \mathrm{Hg}, \mathrm{Cr}$, Co dan $\mathrm{Zn}$ dalam sedimen pada 8 lokasi sampling di Sungai Cimadur.

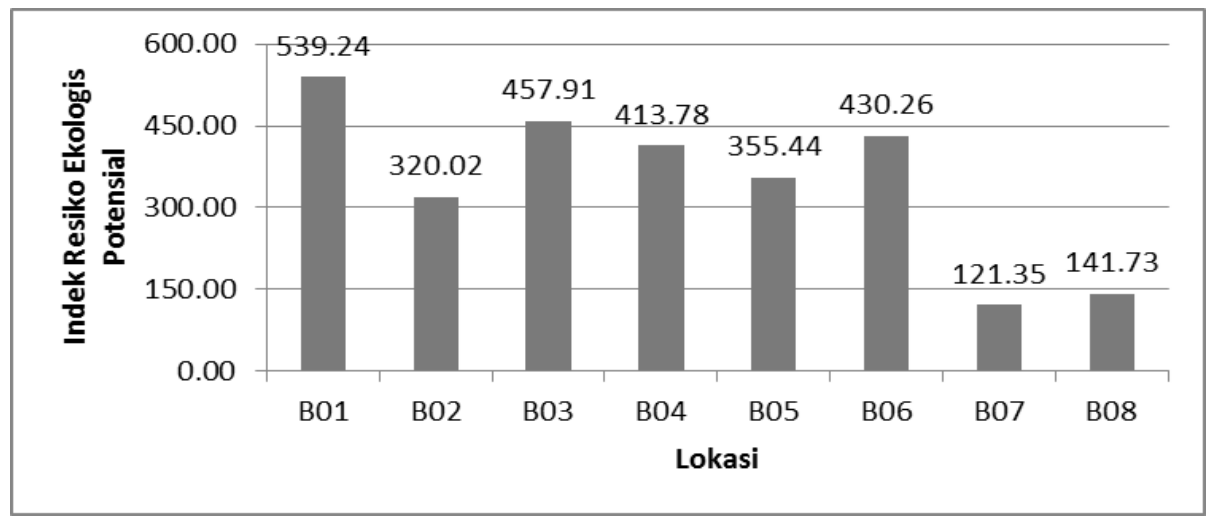

Gambar 7. Indeks resiko ekologis potensial gabungan logam berat $\mathrm{As}, \mathrm{Hg}, \mathrm{Cr}$ dan $\mathrm{Zn}$ dalam sedimen pada 8 lokasi sampling di Sungai Cimadur.

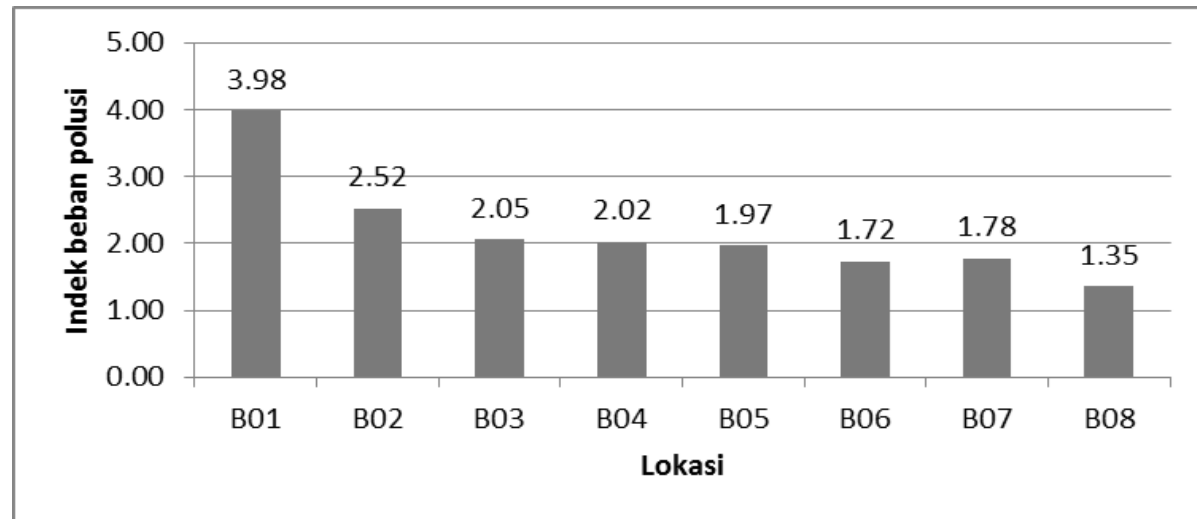

Gambar 8. Indeks beban polusi gabungan logam berat $\mathrm{As}, \mathrm{Hg}, \mathrm{Cr}$, Co dan $\mathrm{Zn}$ dalam sedimen pada 8 lokasi sampling di Sungai Cimadur.

Pada daerah tertentu yang merupakan deposit biji emas, konsentrasi As dan merkuri berada pada konsentrasi yang tinggi karena bebatuan yang membungkus biji emas adalah bebatuan yang mengandung arsenik misal arsenopyrit atau merkuri misal sinabar. Akibat kegiatan penambangan maka bebatuan akan dikeluarkan dari perut bumi dan untuk memperoleh butiran emas lebih efektif dari senyawa induk biasanya digunakan proses 
kimiawi. Pada proses ini selain diperoleh bijih emas, diperoleh juga unsur-unsur ikutan yang merupakan bahan beracun berbahaya. Karena bahan ikutan ini tidak digunakan maka akan dibuang sebagai limbah (tailing) yang dapat mencemari lingkungan.

Pada penambangan emas di Cikotok dalam skala besar digunakan proses sianidasi, dan belakangan penambangan dilakukan secara tradisional oleh rakyat. Untuk mengambil emas, proses kimia yang digunakan adalah proses amalgamasi. Merkuri digunakan untuk mengambil emas dari bijih emas. Amalgamasi merupakan proses ekstraksi emas dengan cara mencampur bijih emas dengan merkuri. Produk yang terbentuk adalah ikatan antara emas-perak dan merkuri yang dikenal sebagai amalgam $(\mathrm{Au}-\mathrm{Hg})$. Air sisa penambangan yang masih mengandung $\mathrm{Hg}$ kemungkinan dibiarkan mengalir ke lingkungan sehingga lingkungan menjadi tercemar. Jadi tingginya konsentrasi $\mathrm{Hg}$ di dalam sedimen sungai Cimadur kemungkinan berasal dari $\mathrm{Hg}$ sendiri yang sebelumnya terkandung dalam bebatuan bumi dan ditambah dengan akibat proses kimiawi yang digunakan untuk pengambilan emas dari bijih emas. Logam berat yang terkandung dalam sedimen sungai Cimadur, terutama $\mathrm{Hg}$ dan As bersifat toksik. Logam ini bersifat akumulatif sehingga dapat memberikan dampak komulatif bagi lingkungan dan biota yang akhirnya dapat berdampak terhadap kesehatan masyarakat. Apalagi dari hasil penelitian menunjukkan bahwa pada lokasi sampling di Sungai Cimadur, daerah tersebut sudah tercemar terutama oleh logam Hg dan As.

\section{KESIMPULAN}

Perhitungan indek polusi unsur logam tunggal maupun gabungan telah digunakan untuk mengevaluasi kualitas sedimen Sungai Cimadur, Cikotok Banten. Hasil penelitian menunjukkan bahwa terjadi peningkatan konsentrasi logam berat $\mathrm{Hg}$, As, $\mathrm{Cr}$, Co dan $\mathrm{Zn}$ akibat pengaruh antropogenik karena kegiatan penambangan emas, terutama untuk logam $\mathrm{Hg}$ dan As sudah pada level rendah hingga ekstrim tinggi. Berdasarkan nilai indek gabungan, diketahui bahwa telah terjadi pencemaran di semua lokasi penelitian, dimana kualitas sedimen memburuk sehingga kemungkinan akan memberikan dampak resiko ekologis tinggi terhadap lingkungan di daerah tersebut yang akan berdampak terhadap biota maupun masyarakat yang tinggal di sekitarnya. Untuk itu perlu strategi pemantauan dan pengelolaan lingkungan yang tepat untuk menurunkan beban pencemaran yang ada di lokasi tersebut, seperti penggunaan amalgam pada pengambilan emas secara tradisonil perlu dipantau, terutama berkaitan dengan pembuangan limbah ke lingkungan.

\section{UCAPAN TERIMA KASIH}

Terima kasih disampaikan kepada rekan-rekan Kelompok AAN dan Fasilitas Iradiasi di PRSG atas kerjasamanya.

\section{DAFTAR PUSTAKA}

1. H. PEKEY, D. KARAKAS, S. AYBERK, L. TOLUN, M. BAKOQLU, Ecological Risk Assesment Using Trace Elements from Surface Sediments of Izmit Bay (Northeastern Marmara Sea) Turkey, Marine Pollution Bulletin, 48 (9-10) (2004) 946 - 953

2. J. KRUOPIENE, Distribution of Heavy Metals in Sediments of the Nemunas River (Lithuania), Polish Journal of Environmental Studies, Volume 6, Issue 5, (2007) 715 - 722

3. L.L. FERNANDES, G.N. NAYAK, Geochemical Assessment in a Creek Environment in Mumbai, West Coast of India, Environ. Foren, 13 (2012) 45 - 54

4. P.S. HARIKUMAR, T.S. JISHA, Distribution pattern of Trace Metal Pollutants in the sediment of an urban wetland in the southwest coast of India, International Journal of Engineering Science and Technology, Volume 2, Issued 5, (2010) 840 - 850

5. GONG QINGJIE, DENG JUN, XIANG YUNCHUAN, WANG QINGFEI, YANG LIQIANG, Calculating Pollution Indices by Heavy Metals in Ecological Geochemistry Assesment and Case Study in Parks of Beijing. Journal of China University of Geosciences, 19 (2008) 230 - 241

6. ANONIM, Extraction/Ekstraksi, http/www.mineraltambang.com/e-book-pertambangan.html, diakses Mei 2014 
7. TH. RINA MULYANINGSIH, ALFIAN, SUTISNA, Distribusi Logam Berat Dalam Sedimen Daerah Aliran Sungai Ciujung Banten, Jurnal Teknologi Reaktor Nuklir Tri Dasa Mega, 14(3) (2012) 137 - 197

8. Google Earth, diakses Juni 2013

9. C.REINMANN, P.DE CARITAT, Distinguishing between Natural and Anthropogenic Source for Elements in the Environment: Regional Geochemical Surveys versus Enrichment Factors. The Science of the Total Environment, 337 (2005) 91 - 107

10. L.P. ZHANG, X. YE, H. FENG, Y.H. JING, T. OUYANG, X.T. YU, R.Y. LING, C.T. GAO, W.Q CHEN, Heavy Metal Contamination in Western Xiamen Bay Sediments and Its Vicinity, China Marine Pollution Bulletin, 54 (2007) $974-982$

11. R.A. SUTHERLAND, Bed Sediment-Associated Trace Metals in an Urban Stream, Oahu, Hawaii, Environmental Geology, 39 (2000) 611 - 627

12. M. CHATTERJEE, F.E. V. SILVA, S.K. SARKAR, et.al., Distribution and Possible Source of Trace Elements in the Sediment Cores of a Tropical Macrotidal Estuary and their Ecotoxicological Significance, Evironment International, 33 (2007) 346 - 356

13. P. BLASER, S. ZIMMERMANN, J. LUSTER, W. SHOTYK, Critical Examination of Trace Enrichments and Depletions in Soil: As, Cr, Cu, Ni, Pband Zn in Swiss Forest Soil, The Science of the Total Environment, 249 (2000) $257-280$

14. K.H. WEDEPOHL, The composition of continental crust, Geochimica et Cosmochimica Acta, 59 (7) (1995) $1217-1232$

15. K.M. BANAT, F.M. HOWARI, A.A. AL-HAMADA, Heavy Metals in Urbam Soils of Central Jordan: Should We worry abaut their Environmental Risks?, Environmental Research, 97 (2005) 258 - 273

16. N.A. SHAFIE, A.Z. ARIS, M.Z. ZKARIA, H. HARIS, W.Y. LIM, N.M. ISA, Application of Geoaccumulation index and enrichment factors on the assessment of Heavy metal pollution in the sediments, Journal of Environmental Science and Health, Part A, 48 (2013) 182 - 190

17. A. BUCCOLIERI, G. BUCCOLIERI, N. CARDELLICCHIO, A. DELL'ATTI, A. DI LEO, A. MACI, Heavy Metals in marine in Marine Sediment of Taranto Gulf (Ionian Sea, Southern Italy), Marine Chemestry 99 (2006) 227 $-235$

18. L. HAKANSON, An Ecological Risk Index for Aquatic Pollution Control: A Sedimentological Approach, Water Research, 14 (1980) 975 - 1001

19. M. SALMANZADEH, M. SAEEDI, G.H. NABI BIDHENDI, Heavy metals pollution in street dusts of Tehran and their ecological risk assessment, Journal of Environmental Studies, 61 (38) (2012) 4 - 6

20. S. CAEIRO, M.H. COSTA, T.B. RAMOS, Assesing Heavy Metal Contamination in Sado Estuary Sedimen: An Index Analysis Approach, Ecological Indicator, 5 (2005) 151 - 169

21. K.B. MMOLOWA, A.S. LIKUKU, GABOUTLOELOE, Assesment of heavy metal pollution in soil along major roadside areas in Botswana, African Journal of Environmental Science \& Technology, 5 (3) (2011) 186 - 196 